IBAD Sosyal Bilimler Dergisi

IBAD Journal of Social Sciences

dergipark.org.tr/ibad

IBAD, 2022; (12): 271-288

DOI: $10.21733 /$ ibad. 988829

Özgün Araştırma / Original Article

\title{
Üniversite Öğrencilerinde İlişkileri Sürdürme Stratejilerinin Yordayıcıları Olarak Romantik İlişki Doyumu ve Romantik İlişkilerde Öz Yeterlik
}

Romantic Relationship Satisfaction and Self-Efficacy in Romantic Relationship As Predictors
of Relationship Maintenance Strategies Among University Students

\section{Samiye Ogan ${ }^{1^{*}}$}

Fatma Selda Öz Soysal ${ }^{2}$

\author{
* Sorumlu yazar \\ Corresponding author
}

${ }^{1}$ Doktora Öğrencisi, Dokuz Eylül Üniversitesi, Türkiye

PhD Student, Dokuz Eylul University, Turkey

ogansamiye@gmail.com

ORCID ID https://orcid.org/0000-0003-4064-0371

${ }^{2}$ Doç. Dr., Dokuz Eylül Üniversitesi, Türkiye

Assoc. Prof. Dr., Dokuz Eylul University, Turkey

seldaoz.oz@gmail.com

ORCID ID https://orcid.org/0000-0001-5406-7786

Makale geliş tarihi / First received : 31.08.2021

Makale kabul tarihi / Accepted : 01.12.2021

\section{Bilgilendirme / Acknowledgement:}

1- Araştırmacıların makale katkı oranı eşittir. Bununla birlikte, makalenin dergiye sunumu, takibi ve sonlandırılması süreçleri sorumlu yazar tarafından yürütülmüştür.

2- Bu makale sorumlu yazarın, ikinci yazar danışmanlığında yürüttüğü “Üniversite Öğrencilerinin İlişkileri Sürdürme Stratejilerinin, Bağlanma Stilleri, Romantik İlişki Doyumu ve Romantik İlişkilerde Öz Yeterlik İle Arasındaki İlişkilerin İncelenmesi" adlı yüksek lisans tezinden üretilmiştir.

3- Makalenin yazarları arasında çıkar çatışması bulunmamaktadır.

4- Ölçeklerin çalışmada kullanılabilmesi için ölçekleri geliştiren ve uyarlayan kişilerden e-posta yoluyla ölçek izinleri alınmıştır. Dokuz Eylül Üniversitesi Sosyal ve Beşeri Bilimler Araştırma ve Yayın Etik Kurulunun 05.11.2020 tarihli toplantısında alınan 23 sayılı karar ile etik kurulu izni alınmıştır.

5- Bu makalede araştırma ve yayın etiğine uyulmuştur.

This article was checked by iThenticate. Similarity Index $18 \%$

\section{Atıf bilgisi / Citation:}

Ogan, S. \& Öz Soysal, F. S. (2022). Üniversite öğrencilerinde ilişkileri sürdürme stratejilerinin yordayıcıları olarak romantik ilişki doyumu ve romantik ilişkilerde öz yeterlik. IBAD Sosyal Bilimler Dergisi, (12), 271-288. 
ÖZ

$\mathrm{Bu}$ araştırmanın amacı, üniversite öğrencilerinin romantik ilişki doyumu ve romantik ilişkilerde öz yeterlik düzeylerinin, ilişkileri sürdürme stratejilerini yordama gücünü belirlemektir. Araştırmanın çalışma grubunu, Ege Bölgesi'nde bir devlet üniversitesinin çeşitli fakülte ve bölümlerinde öğrenim gören 260' 1 (\%64) kadın 146'sı (\%36) erkek olmak üzere toplam 406 üniversite öğrencisi oluşturmaktadır. Araştırmada, veri toplama araçları olarak "İlişkileri Sürdürme Stratejileri Ölçeği", "Romantik İlişkilerde Doyum Ölçeği", "Romantik İlişkilerde Öz Yeterlik Ölçeği" ve "Kişisel Bilgi Formu" kullanılmıştır. Verilerin çözümlenmesinde, aşamalı regresyon analizi uygulanmıştır. Araştırmadan elde edilen bulgular, romantik ilişki doyumu ve romantik ilişkilerde öz yeterliğin ilişki sürdürme stratejilerine yönelik toplam varyansın \%53.3'ünü açıkladığını ve ilişki sürdürme stratejilerinin en güçlü yordayıcısının romantik ilişki doyumu olduğunu göstermektedir. Sonuç olarak, üniversite öğrencilerinin ilişki sürdürme becerilerinin geliştirilmesine, romantik ilişkilerde doyum ve romantik ilişkilerde öz yeterlik düzeylerinin artırılmasına yönelik programların geliştirilmesi ve uygulanması önerilmektedir.

\section{ABSTRACT}

The aim of this study is; to determine the predictive power of university students' romantic relationship satisfaction and self-efficacy in romantic relationships levels on relationship maintenance strategies. The study group of the research consists of a total of 406 university students, $260(64 \%)$ female and $146(36 \%)$ male, studying in various faculties and departments of a state university in the Aegean Region. In the research, "Relationship Maintenance Strategies Scale", "Romantic Relationship Satisfaction Scale", "Self-Efficacy in Romantic Relationships Scale" and "Personal Information Form" were used as data collection tools. In the data analysis, stepwise regression analysis was performed. Findings from the study show that romantic relationship satisfaction and self-efficacy in romantic relationships explain $53.3 \%$ of the total variance in relationship maintenance strategies, and romantic relationship satisfaction is the strongest predictor of relationship maintenance strategies. As a result, it is recommended to develop and implement programs to improve the relationship maintenance skills of university students, to increase their satisfaction in romantic relationships and their self-efficacy levels in romantic relationships.

\author{
Anahtar kelimeler \\ İlişkileri sürdürme stratejileri, romantik ilişki doyumu, \\ romantik ilişkilerde öz yeterlik, romantik ilişki
}

\section{Keywords}

Relationship maintenance strategies, romantic relationship satisfaction, self-efficacy in romantic relationships, romantic relationship 


\section{GİRiş}

Üniversite yaşantısı, kimlik gelişimi, yeni sosyal çevreye uyum ve yakın ilişkiler kurabilme gibi beliren yetişkinlik dönemine özgü birçok gelişimsel görevin de içinde yer aldığ bir süreci oluşturur. Bu dönemde birey, yaşamının her alanında bir kimlik oluşturma süreci içerisinde olmaktadır. Sosyal bir varlık olması ve gelişimsel görevlerini tamamlayabilmesi adına birey, aynı zamanda yakın ilişki kurma ihtiyacını karşılama çabasına da girme eğilimindedir.

Yakın ilişkiler kurmak, bireyin yaşamında mutlu olmasında ve kendini güvende hissedebilmesinde rol alan en önemli kaynaklardan birisidir. Yakın ilişkiler kapsamında yer alan ve bu ilişkilerin bir parçasını oluşturan romantik ilişkiler ise 18-26 yaş arasındaki üniversite öğrencilerinin yaşamlarının neredeyse merkezini oluşturmakta ve en önemli psikososyal gelişim görevleri arasında yer almaktadır (Kuttler ve Greca, 2004). Romantik ilişkiler; evlilik, flört, uzun süreli birliktelik gibi kişiler arası ilişkileri içinde barındıran bir yapıya sahiptir (Hendrick ve Hendrick, 2006). Collins (2003), romantik ilişkiyi her iki tarafın da gönüllü olarak içinde bulunduğu bir ilişki türü olarak tanımlamakta olup romantik ilişkinin katılım, eş seçimi, ilişki kalitesi, ilişki içeriği ile duygusal ve bilişsel süreçler olmak üzere ayırt edici beş özelliği olduğunu vurgulamaktadır. Bu ayırt edici beş özelliğin olumlu sonuçlanması, romantik ilişkilerin istikrarında oldukça önem arz eder. İlişkilerin mutlu ve istikrarlı olmasında, ilişkileri sürdürme aktif bir rol oynamaktadır (Weiser ve Weigel, 2016). Bu kapsamda ilişkileri sürdürmede kullanılan stratejiler aktif rol üstlenir. İlişkileri sürdürme, değerli olan bir ilişkinin devamlılığını sağlamak, ilişkinin sonlanmasını önlemek, ilişkiyi ilerletmek ya da sonlanan bir ilişkiyi yeniden kurmak için gösterilen birbiri ile iç içe geçmiş davranışlardır. Canary ve Stafford'a (1992) göre, ilişkileri sürdürme davranışlarının; pozitiflik (olumlu duygular, neşeli bir duygu durum vb.), açıklık (kendini açma), güvenceler (sadakat, sevgi vb.), sosyal ağlar (destekleyici tavır ve ortak sosyal yaşam) ve görev paylaşımı (sorumluluk) olmak üzere beş temel türü vardır. Pozitiflik, partnerler arasındaki etkileşimlerin neşeli ve pozitif tutulmaya çalışılmasıdır. Pozitiflik, eleştiriden kaçınma ve eğlenceli faaliyetlere dahil olma gibi davranışları içerir. Açılılk, partnerlerin birbirlerine karşı dürüst olmalarını ve duygularını açıça ifade etmelerini kapsar. Ayrıca, partnerlerin ilişkiye yönelik hedeflerini ve beklentilerini ifade etmeleri de açılık olarak değerlendirilmektedir. İlişkiyi sürdürme sırasında ortaya çıkan bu beklentiler, bireysel sorunlara veya duygulara odaklanan beklentilerden daha çok ilişkiye odaklanan beklentilerden oluşmaktadır. Güvenceler, bireyin partnerlerine yönelik bağlılığını gösteren, sadakatini vurgulayan ve partnere destek olmayı içeren davranışlardır (Stafford ve Canary, 1991). Sosyal ağlar, istikrarlı ilişkiler kurulmasına yardımcı olan kaynakları -arkadaşları ve aileleri- içeren bakım stratejisidir. Bireylerin ailelerini hafta sonu ziyaret etmeleri, ortak arkadaşlara sahip olmaları ve arkadaşlarıyla ortak faaliyetlere katılım göstermeleri ilişkiyi desteklemeye yardımcı olan davranışlardır. Bu davranışlar, sosyal ağlar bağlamında ele alınır. Son olarak, görev paylaşımı, partnerlerin sorumlulukları paylaşmalarını ve adil bir şekilde bu görevleri yerine getirmelerini içerir. Görüldügü üzere ilişki sürdürme davranışları, pozitiflik, açıklık gibi doğrudan iletişimi içeren etkileşimli davranışların yanı sıra, görevleri paylaşma ve sosyal ağlar gibi etkileşimsiz bazı davranışları da içerir.

İlişki sürdürme davranışları beş bağlamda ele alınsa da ilişki sürdürme kavramının sınırları oldukça belirsizdir. Bu nedenle partnerlerin, romantik ilişkilerini sürdürme şekilleri önemli 
ölçüde değişkenlik gösterir. Yıllar boyunca çok çeşitli disiplinlerde, çiftlerin yakın ilişkilerini nasıl ve neden aktif olarak sürdürmeye çalıştıkları ele alınmıştır (Canary ve Dainton, 2006; Wenzel ve Harvey, 2001; Rusbult vd. 2001). Bu bağlamda bireylerin, bir ilişkiyi doyum sağlayan bir durumda tutmak ve/veya kötüleşmesini önlemek için ilişki sürdürme stratejilerini kullandıkları belirlenmiştir (Dindia, 2000). Duck (1988), ilişkileri sürdürme stratejilerinin, bir ilişkiyi sürdürmeye, zor zamanlardan geçmiş bir ilişkiyi ise onarmaya yönelik sergilenen çabaları içerdiğini belirtmektedir. İlişkileri sürdürme stratejileri; bağlılık, ilişkisel doyum, istikrar ve sevgi gibi bazı önemli ilişkisel özellikleri de içerir (Ogolsky ve Bowers, 2013).

Bazı bireyler ilişkilerini sürdürmede etkililik gösterebilirken bazı bireyler etkililik gösterememekte ve ilişkileri sonlanmaktadır. Romantik ilişkinin istenmeyen bir sonucu olan ayrılık durumunda, partnerlerin işlevsel olmayan stratejiler kullanmasının yanı sıra ilişkileri hakkında yaptıkları değerlendirmeler de önemli bir rol üstlenir. Yapılan bu değerlendirmeler; romantik ilişkinin sürdürülmesini, romantik ilişki kalitesini ve romantik ilişki doyumunu yakından etkiler. Bireyin ilişkisi hakkında yaptığı öznel değerlendirmeler, ilişki doyumu olarak ifade edilir. İlişkiye yönelik öznel değerlendirmelerin olumlu yönde olması, ilişki doyumunun yüksek olduğunu gösterir. Öznel değerlendirmelerin yanı sıra bireylerin ilişkilerine ve partnerlerine yönelik beklentileri ile partnerinin beklentilerini karşılayabilme dereceleri de ilişki doyumunun şekillenmesinde etkilidir (Rusbult ve Buunk, 1993). Romantik ilişkilerinde beklentileri karşılanan bireyler, romantik ilişkilerini olumlu yönde; beklentileri karşılanmayan bireyler ise romantik ilişkilerini olumsuz yönde değerlendirme eğilimine sahiptir.

İlişki sürdürme stratejilerinin sık kullanılması durumunda, romantik ilişki doyumu artmakta (Canary ve Stafford, 1992; Stafford ve Canary, 2006) ve ilişkilerin istikrarlı (Canary vd., 2002) olması sağlanmaktadır. Romantik ilişkilerin kurulmasında, sürdürülmesinde ve farklı ilişkilerde deneyimlenen sorunların anlaşılmasında, etkili ilişkiler kurmaya ve zorluklar ile baş etmeye yönelik yeteneklere ilişkin inançlar oldukça önemli bir yere sahiptir. Romantik ilişkilerde öz yeterlik, partnerlerin romantik ilişki içerisindeki yaşantıları ile baş etme becerilerine yönelik algılarıdır. Lopez vd.'e göre (2007) göre romantik ilişkilerde öz yeterlik, partnerlerin bireysel ihtiyaçlarını ifade etmeye, duygularını kontrol etmeye, çatışmaları çözmeye ve ilişkilerini sürdürme ile ilgili yeterliklere yönelik öznel değerlendirmeleridir. Öz yeterlikleri yüksek olan bireyler, amaçlarına ulaşmada ve zorlu yaşam olaylarıyla baş etmede daha fazla çaba ve sabır gösterme eğilimindedir (Bandura, 1994). Lopez vd. (2007) ilişki öz yeterliğinin sağlanmasında; karşılıklılık, duygusal kontrol ve farklılaşma olmak üzere üç faktörün etkili olduğunu belirtmektedir. İlişkileri beslemeye, partnere destek vermeye ve partnerden destek görmeye yönelik geliştirilen algılar, karşılıklılık olarak ifade edilir. İlişki içerisinde deneyimlenen olumsuz duyguların yapıcı bir şekilde yönetilebilmesi, duygusal kontrol olarak tanımlanır. Kişisel sınırları korumaya yönelik ihtiyaçları ifade etme becerisi ise farklılaşma olarak ele alınır (Lopez vd., 2007). Romantik ilişkilerde öz yeterlik, açık iletişim kurmada, destek vermede, ilişkiyi beslemede ve öfke ile acı veren duyguları kontrol etmede partnerlerin kendilerine güvenini içerir (Lopez vd., 2007). Etkili bir romantik partner olabileceğine yönelik inanca sahip bireyler, romantik ilişkilerinin başarılı olacağı konusunda daha büyük beklentilere, daha düşük kaygı seviyesine ve gerginliğe sahip olmaktadır (Riggio vd., 2011). Fincham vd. (2000) ise, yüksek beklentilerin, yüksek ilişki doyumuyla ilişkili 
olduğunu ve partnerlere yönelik olumlu algıların geliştirilmesinde aktif rol aldığını ifade etmektedir.

İlgili alan yazında ilişkileri sürdürme kavramının, ilişkiyi mevcut konumunda tutmak için mi yoksa ilişkiyi sürdürmek/geliştirmek için mi tasarlandığı konusunda birtakım anlaşmazlıklar mevcuttur. İlişkileri sürdürme stratejilerini ele alan araştırmaların, daha çok ilişkileri sürdürmenin tanımı ve sürdürme stratejilerinin kapsamı üzerinde şekillendiği gözlemlenmektedir. İlişki doyumu kavramının ise sıklıkla; akılcı olmayan inançlar (Saraç, Hamamcı ve Güçray, 2015; Sarı, 2008; Stackert ve Bursik, 2003), ilişki kalitesi (Brewer ve Abell, 2017), bağlanma stili (Gleeson ve Fitzgerald, 2014; Roberts ve Pistole, 2009), çatışma stili (Cramer, 2002; Cramer, 2004) ve toplumsal cinsiyet (Sakallı Uğurlu, 2003) ile ilişkilendirildiği görülmektedir. İlgili alanyazında romantik ilişkilerde öz yeterlik ile ilgili yürütülen çalışmaların oldukça sınırlılık gösterdiği; çalışmaların, ilişkisel benlik değişimi (Gündüz ve Karataş, 2020), ilişki doyumu (Fincham vd., 2000; Lopez vd., 2007; Weiser ve Weigel, 2016) ve ilişki kalitesi (Cui vd., 2008) üzerinde şekillendiği gözlemlenmektedir. Yurt içinde ve yurt dışında konuyla ilgili yürütülen çalışmaların oldukça sınırlılık göstermesi, konuyla ilgili daha çok araştırmanın yürütülmesini gerekli kılmaktadır.

Bireylerin yaşantılarının merkezinde yer alan romantik ilişkiler, alanyazında da uzun zamandır ele alınan kavramların başında gelmektedir. Alanyazında ilişki sürdürme stratejilerinin ilişkili olduğu değişkenler konusunda yeterli araştırmaya ulaşılamamış olup; ilişki sürdürme stratejilerinin, romantik ilişki doyumu ve romantik ilişkilerde öz yeterlik ile ilişkisini ele alan çalışma, Weiser ve Weigel (2016) tarafından yürütülmüştür. Weiser ve Weigel (2016) gerçekleştirdikleri çalışmada, ilişki sürdürme stratejilerinin, romantik ilişkilerde öz yeterlik ve romantik ilişki doyumu arasındaki ilişkiye aracılık ettiğini tespit etmişlerdir. İlişkileri sürdürme stratejileri ile ilgili yurtdışında yapılan çalışmalara oranla ülkemizde yapılan çalışma sayısının oldukça sınırlılık gösterdiği gözlemlenmektedir. Bu kapsamda, ilişkileri sürdürme stratejileri ile romantik ilişki doyumu ve romantik ilişkilerde öz yeterlik değişkenleri arasındaki ilişkilerin kavranmasının, sağlıklı romantik ilişkilerin kurulabilmesi, sürdürülebilmesi, ilişkileri sürdürme becerilerine yönelik programların oluşturulması ve uygulanması bakımından ilgili alanyazına katkı sağlayacağı düşünülmektedir. Bu çalışmanın amacı, üniversite öğrencilerinin romantik ilişki doyumu ve romantik ilişkilerde öz yeterlik düzeylerinin, ilişkileri sürdürme stratejilerini yordama gücünü belirlemektir.

\section{YÖNTEM}

\section{Araştırmanın Modeli}

$\mathrm{Bu}$ çalışma, iki ve daha çok sayıdaki değişken arasındaki değişimin varlığını ve derecesini belirlemeyi amaçlamakta olan genel tarama modellerinden "ilişkisel tarama" modeline göre desenlenmiştir. Tarama modelleri "geçmişte ya da halen var olan bir durumu, var olduğu şekliyle betimlemeyi amaçlayan araştırma yaklaşımlardır” (Karasar, 2012, s. 77).

\section{Çalışma Grubu}

Araştırmanın çalışma grubunu, 2020-2021 eğitim-öğretim yılında öğrenim gören, Ege Bölgesi'nde yer alan bir devlet üniversitesinin Eğitim Fakültesi, Hukuk Fakültesi, Fen ve Edebiyat Fakültesi, İktisadi ve İdari Bilimler Fakültesi, Mühendislik Fakültesi, Mimarlık 
Fakültesi, Tıp Fakültesi, Hemşirelik Fakültesi, Diş Hekimliği Fakültesi ve Sağlık Bilimleri Fakültesi öğrencileri oluşturmaktadır. Çalışma grubunun belirlenmesinde, basit (seçkisiz) örnekleme yöntemi kullanılmış olup 406 üniversite öğrencisi çalışmaya dâhil edilmiştir. Basit (seçkisiz) örnekleme yöntemi, evren listesinden örnekleme birimlerinin rastgele seçilmesini içermektedir (Büyüköztürk vd., 2018). Araştırmanın çalışma grubunun belirlenmesinde, "Ege Bölge'sinde yer alan bir devlet üniversitesinde öğrenim görmek" ve "şu anda ya da geçmişte romantik ilişki yaşantısına sahip olmak" gibi dâhil etme kriterleri kullanılmıştır.

Araştırmanın çalışma grubunu oluşturan katılımcıların, öğrenim gördükleri fakültelere göre dağ 1 lımı Tablo 1'de sunulmuştur.

Tablo 1. Çalışma Grubunu Oluşturan Katılımcıların Öğrenim Gördükleri Fakültelere Göre Dă̆ılımı

\begin{tabular}{ccc} 
Fakülteler & f & \% \\
\hline Eğitim Fakültesi & 139 & 34.2 \\
İktisadi ve İdari Bilimler Fakültesi & 64 & 15.8 \\
Mühendislik Fakültesi & 46 & 11.3 \\
Tıp Fakültesi & 35 & 8.6 \\
Hemşirelik Fakültesi & 31 & 7.6 \\
Diş Hekimliği Fakültesi & 26 & 6.4 \\
Fen ve Edebiyat Fakültesi & 24 & 5.9 \\
Mimarlık Fakültesi & 21 & 5.2 \\
Hukuk Fakültesi & 18 & 4.5 \\
Sağllk Bilimleri Fakültesi & 2 & 0.5 \\
Toplam & 406 & 100 \\
\hline
\end{tabular}

Veri Toplama Araçları

Araştırmada; araştırmacı tarafından hazırlanan "Kişisel Bilgi Formu", "İlişkileri Sürdürme Stratejileri Ölçeği (İSSÖ)”, “Romantik İlişkilerde Doyum Ölçeği (RIDÖ)”, “Romantik İlişkilerde Öz Yeterlik Ölçeği (RIÖYÖ)” veri toplama araçları olarak kullanılmıştır.

\section{Kişisel Bilgi Formu}

Araştırmacı tarafından oluşturulan kişisel bilgi formu, cinsiyet, yaş, ilişki süresi gibi değişkenleri içeren ve bireylerin romantik ilişkilerine yönelik duygu ve düşüncelerini belirlemeyi amaçlayan bir formdur.

\section{İlişkileri Sürdürme Stratejileri Ölçeği (İSSÖ)}

Canary ve Stafford (1992) tarafından geliştirilen “İlişkileri Sürdürme Stratejileri Ölçeği”, 5'li likert tipi bir ölçek olup toplam 29 maddeden oluşmaktadır. Ölçek maddeleri, 1 (kesinlikle katılmıyorum), 2 (katılmıyorum), 3 (biraz katılmıorum), 4 (ne katılıorum ne katılmiyorum), 5 (biraz katılıyorum), 6 (katılıyorum), 7 (tamamen katılıyorum) şeklinde puanlandırılmıştır. Ölçek pozitiflik, açıklık, güvenceler, sosyal ağlar ve görev paylaşımı olmak üzere beş alt boyuttan oluşmaktadır. İlişkiyi Sürdürme Stratejileri Ölçeği, Öz Soysal ve diğerleri (2019a) tarafından Türkçeye uyarlanmıştır. İlişkiyi Sürdürme Stratejileri Ölçeği'nin uyarlama çalışması, 352'si kı, 126'sı erkek olmak üzere toplam 478 üniversite öğrencisi üzerinde yürütülmüştür. Ölçeğin Cronbach Alfa katsayısı, pozitiflik alt boyutu için .95, açılık alt boyutu için .96 , güvenceler alt boyutu için .96 , sosyal ağlar alt boyutu için .95 , görev paylaşımı 
alt boyutu için .97 ve toplam ölçek için ise .98 olarak bulunmuştur. Bu çalışmada ise; İlişkileri Sürdürme Stratejileri Ölçeği'nin Cronbach alfa katsayısı .92 olarak tespit edilmiştir. Analiz sonuçları, Türk kültürüne uyarlanan ölçeğin üniversite öğrencileri için uygulanılabilecek, geçerli ve güvenilir bir ölçme aracı olduğunu destekler niteliktedir.

\section{Romantik İlişkilerde Doyum Ölçeği (RİDÖ)}

"Romantik İlişkilerde Doyum Ölçeği”, Sakallı Uğurlu (2003) tarafından romantik ilişkilerdeki doyumu ölçmek amacı ile geliştirilmiş olup, 7'li likert tipinde bir ölçektir. Ölçeğin üst kısmında, "Genel olarak partnerimle------ bir ilişkim var" ifadesi yer almaktadır. Katılımcılardan, 9 sıfat çiftini okuyup, hangi sıfatın romantik ilişkilerini tanımladıklarını belirtmeleri istenmektedir: tutkulu-tutkusuz, ödüllendirici-cezalandırıcl, sevgi dolu-nefret dolu, tatmin edici-tatmin edici olmayan, zevkli-sinir bozucu, mutlu-mutsuz, iyi-kötü, heyecanlı-heyecansız ve memnuniyetsiz-memnuniyet verici. Katılımcılardan ayrıca ölçeğin sonunda yer alan: "Kapsamlı olarak, partnerimle olan ilişkimden memnunum." ifadesini değerlendirmeleri beklenmektedir. Ölçeğin iç tutarlılığının hesaplanmasında, Cronbach alfa katsayısı kullanılmıştır ve bu değer .90 olarak belirlenmiştir. Bu çalışmada ise; Romantik İlişkilerde Doyum Ölçeği'nin Cronbach alfa katsayısı .90 olarak tespit edilmiştir. Analiz sonuçları, Türk kültürüne uyarlanan ölçeğin araştırma için geçerli ve güvenilir bir ölçme aracı olduğunu destekler niteliktedir.

\section{Romantik İlişkilerde Öz Yeterlik Ölçeği (RIÖYÖ)}

Riggio ve diğerleri (2011) tarafından geliştirilen "Romantik İlişkilerde Öz Yeterlik Ölçeği", romantik ilişkilerdeki istekleri karşılama kapasitesine yönelik bireylerin partner olarak yeteneklerine ilişkin inançlarını ölçmektedir. Ölçek, toplam 12 maddeden oluşmakta olup maddeleri 1 (kesinlikle katılmıyorum), 5 (ne katılıyorum ne katılmıorum), 9 (tamamen katılıyorum) arasında puanlanan 9'lu likert tipi bir ölçektir. Romantik İlişkilerde Öz Yeterlik Ölçeği, Öz Soysal ve diğerleri (2019b) tarafından Türkçeye uyarlanmıştır. Romantik İlişkilerde Öz Yeterlik Ölçeği'nin uyarlama çalışması, 243'ü kız ve 124'ü erkek olmak üzere toplam 367 üniversite öğrencisi üzerinde yürütülmüştür. Ölçeğin, 2 faktör yapısı olup, faktör 1, olumsuz olarak ele alınmış olup bir partner olarak bireyin yeteneklerini ve kişisel güçlüklerini kapsayan yargılardan oluşmakta iken faktör 2, olumlu olarak ele alınıp ilişkilerdeki görevlerini yerine getirme sürekliliğini kapsamaktadır. Ölçeğin iç tutarlılığının hesaplanmasında, Cronbach alfa katsayısı kullanılmıştır ve bu katsayı .89 olarak tespit edilmiştir. Bu çalışmada ise; Romantik İlişkilerde Öz Yeterlik Ölçeği'nin Cronbach alfa katsayısı .88 olarak tespit edilmiştir. Analiz sonuçları, Türk kültürüne uyarlanan ölçeğin üniversite öğrencileri için uygulanılabilecek, geçerli ve güvenilir bir ölçme aracı olduğunu destekler niteliktedir.

\section{Verilerin Toplanması}

Araştırma kapsamında verilen toplanmasına yönelik, Bilimsel Araştırma ve Yayın Etiği Kurulu'na başvuru yapılmıştır. Dokuz Eylül Üniversitesi'nin Sosyal ve Beşeri Bilimler Araştırma ve Yayın Etik Kurulunun 05.11.2020 tarihli toplantısında alınan 23 sayılı karar ile etik kurulu izni alınmıştır. Etik kurul izninin ardından, Ege Bölgesi'nde yer alan bir devlet üniversitesinin çeşitli fakülte ve bölümlerinde, 2020-2021 eğitim-öğretim yılında öğrenim gören üniversite öğrencilerine ulaşılmıştır. Verilerin toplanmasında araştırmacı tarafından çevrim içi platformda hazırlanan formlardan yararlanılmıştır. Araştırmacı tarafından 
araştırmada kullanılan "İlişkileri Sürdürme Stratejileri Ölçeği”, "İlişki Ölçekleri Anketi”, "Romantik İlişkilerde Doyum Ölçeği", "Romantik İlişkilerde Öz Yeterlik Ölçeği" ve "Kişisel Bilgi Formu" Google Anket formatına dönüştürülmüştür. Çevrim içi olarak katılımcılara ulaştırılan formlar aracılığıyla, veri toplama süreci tamamlanmıştır. Veri toplama sürecinde, katılımcılara araştırmaya katılımın gönüllülük esasına dayandığı, araştırmada kullanılacak bilgilerin yalnızca bilimsel amaçlar için kullanılacağı ve gizlilik esası gözetileceği açıklanmıştır. Araştırmanın amacına, önemine ve kullanılan ölçeklere ilişkin bilgiler, çevrim içi formun ilk kısmında belirtilmiştir. Ayrıca katılımcılara, araştırma bulgularının gerçekleri yansıtması için soruları içtenlikle cevaplamalarının önemine yönelik bilgilendirme sağlanmıştır. Veri toplama uygulaması, yaklaşık 30 dakika sürmüştür.

\section{Verilerin Analizi}

Verilerin analizi, SPSS 24.0 paket programından yararlanılarak gerçekleştirilmiştir. Çalışmada, parametrik ya da parametrik olmayan analiz yöntemlerinden yararlanmayı belirlemek amacıyla normal dağılım göstergeleri (Shapiro-Wilk ile Kolmogorov-Smirnov normallik testleri, basıklık ve çarpıklık değerleri, Q-Q grafikleri ve histogramlar) incelenmiştir. Basıklık ve çarpıklık katsayılarının \pm 1.5 aralığında yer alması, verilerin normal dağılım gösterdiğini ifade etmektedir (Tabachnick ve Fidell, 2015). Bu bağlamda, ilgili veri setinin normallik varsayımını karşıladığı belirlenmiştir. Bağımlı ve bağımsız değişkenler arasındaki ilişkiler, Pearson korelasyon analizi ile değerlendirilmiştir. Son aşamada; bağımsız değişkenlerin, bağımlı değişkeni yordama durumunu belirlemek amacıyla aşamalı regresyon (stepwise) analizi tekniğinden yararlanılmıştır.

\section{BULGULAR}

Bu bölümde, İlişki Sürdürme Stratejileri Ölçeği, Romantik İlişkilerde Doyum Ölçeği ve Romantik İlişkilerde Öz Yeterlik Ölçeği'nden elde edilen toplam puanlara ilişkin betimsel istatistiklere, veri analizi sonucu elde edilen bulgulara ve bulgulara yönelik yapılan değerlendirmelere yer verilmektedir.

İlişki Sürdürme Stratejileri, Romantik İlişkilerde Doyum ve Romantik İlişkilerde Öz Yeterlik Ölçeklerine ait Kolmogorov-Smirnov test ve ShapiroWilk test sonuçları, Tablo 2'de sunulmuştur.

Tablo 2. İlişki Sürdürme Stratejileri, Romantik İlişkilerde Doyum ve Romantik İlişkilerde Öz Yeterlik Ölçeklerine Ait Kolmogorov-Smirnov test ve ShapiroWilk test Sonuçları

\begin{tabular}{lcccccc}
\hline Ölçekler & \multicolumn{3}{c}{ Kolmogorov-Smirnov testi } & \multicolumn{3}{c}{ Shapiro-Wilk testi } \\
\hline & İstatistik & $\mathbf{S}_{\boldsymbol{d}}$ & $\mathbf{p}$ & İstatistik & $\mathbf{S}_{\boldsymbol{d}}$ & $\mathbf{p}$ \\
\hline İlişki Sürdürme Stratejileri Toplam & .134 & 406 & .050 & .903 & 406 & .090 \\
Romantik İlişkilerde Doyum Toplam & .130 & 406 & .045 & .890 & 406 & .086 \\
Romantik İlişkilerde Öz Yeterlik Toplam & .224 & 406 & .062 & .831 & 406 & .080 \\
\hline
\end{tabular}

${ }^{*} \mathrm{p}<.05$

İlişkileri Sürdürme Stratejileri Ölçeği'ne ait \%95 güven aralığında Kolmogorov-Smirnov test sonuçlarına göre anlamlılık değeri $\mathrm{p}=.050$; Shapiro-Wilk test sonuçlarına göre anlamlılık değeri $p=.090$ bulunmuştur. Elde edilen değerlerin $p>.05$ olması, ilgili veri setinin normale yakın dağılım gösterdiğine işaret etmektedir. Romantik İlişkilerde Doyum Ölçeği'ne ait \%95 
güven aralığında Kolmogorov-Smirnov test sonuçlarına göre anlamlılık değeri $p=.045$; Shapiro-Wilk test sonuçlarına göre anlamlılık değeri $\mathrm{p}=.086$ bulunmuştur. Elde edilen değerlerin p>.05 olması, ilgili veri setinin normale yakın dağılım gösterdiğine işaret etmektedir. Romantik İlişkilerde Öz Yeterlik Ölçeği'ne ait \%95 güven aralığında KolmogorovSmirnov test sonuçlarına göre anlamlılık değeri $p=.062$; Shapiro-Wilk test sonuçlarına göre anlamlılık değeri $\mathrm{p}=.080$ bulunmuştur. Elde edilen değerlerin $\mathrm{p}>.05$ olması, ilgili veri setinin normale yakın dağılım gösterdiğine işaret etmektedir.

Araştırma kapsamında, katılımcılara uygulanan ölçeklerin toplam ölçek puanlarına ilişkin ortalama, standart sapma, basıklık ve çarpıklık değerleri hesaplanarak Tablo 3 'te sunulmuştur.

Tablo 3. İlişki Sürdürme Stratejileri Ölçeği, Romantik İlişkilerde Doyum Ölçeği ve Romantik İlişkilerde Öz Yeterlik Ölçeŏi'ne İlişkin Betimsel İstatistikler

\begin{tabular}{|c|c|c|c|c|c|c|c|}
\hline \multirow[t]{2}{*}{ Ölçekler } & \multirow[b]{2}{*}{$\mathbf{n}$} & \multirow[b]{2}{*}{$\bar{x}$} & \multirow[b]{2}{*}{$S_{d}$} & \multicolumn{2}{|c|}{ Çarpıklık } & \multicolumn{2}{|c|}{ Basıklık } \\
\hline & & & & Katsay1 & $\begin{array}{l}\text { Standart } \\
\text { Hata }\end{array}$ & Katsayı & $\begin{array}{l}\text { Standart } \\
\text { Hata }\end{array}$ \\
\hline İlişki Sürdürme Stratejileri Toplam & 406 & 161.56 & 21.31 & -1.09 & .12 & .93 & .24 \\
\hline Romantik İlişkilerde Doyum Toplam & 406 & 57.67 & 8.16 & -.94 & .12 & -.08 & .24 \\
\hline $\begin{array}{l}\text { Romantik İlişkilerde Öz Yeterlik } \\
\text { Toplam }\end{array}$ & 406 & 79.63 & 14.26 & -.61 & .12 & 1.45 & .24 \\
\hline
\end{tabular}

Tablo 3 incelendiğinde, "İlişki Sürdürme Stratejileri Ölçeği" ( $\left.x=161.56, S_{d}=21.31\right)$ "Romantik İlişkilerde Doyum Ölçeği" ( $\left.x^{-}=57.67, S_{d}=8.16\right)$ ve "Romantik İlişkilerde Öz Yeterlik Ölçeği" ( $x$ $\left.=79.63, S_{d}=14.26\right)$ puan ortalamaları ve standart sapmaları da yer almaktadır. Ölçeklerin çarpıklık katsayıları -1.09ile -.61 ve basıklık katsayıları -.08ile 1.45 arasında yer almaktadır. Verilerin normal dağılım varsayımını karşılaması, basıklık ve çarpıklık katsayılarının \pm 1.5 aralığında yer alması ile mümkün olmaktadır (Tabachnick ve Fidell, 2015). Bu kapsamda elde edilen değerler incelendiğinde, verilerin normal dağılım varsayımını karşıladığı söylenebilir.

Üniversite öğrencilerinin İlişki Sürdürme Stratejileri Ölçeği, Romantik İlişkilerde Doyum Ölçeği ve Romantik İlişkilerde Öz Yeterlik Ölçeği toplam ölçek puanları arasındaki ilişkiler Pearson korelasyon analizi ile değerlendirilmiş, sonuçlar Tablo 4'te sunulmuştur.

Tablo 4. İlişki Sürdürme Stratejileri, Romantik İlişkilerde Doyum ve Romantik İlişkilerde Öz Yeterlik Ölçekleri Arasındaki İlişkiler

\begin{tabular}{lccc}
\hline Ölçekler & $\begin{array}{c}\text { Illişki Sürdürme } \\
\text { Stratejileri } \\
\text { Toplam }\end{array}$ & $\begin{array}{c}\text { Romantik } \\
\text { Illişkilerde } \\
\text { Doyum } \\
\text { Toplam }\end{array}$ & $\begin{array}{c}\text { Romantik } \\
\text { Illişkilerde Öz } \\
\text { Yeterlik } \\
\text { Toplam }\end{array}$ \\
\hline İlişki Sürdürme Stratejileri Toplam & 1 & $.701^{* *}$ & $.559^{* *}$ \\
Romantik İlişkilerde Doyum Toplam & $.701^{* *}$ & 1 & $.555^{* *}$ \\
Romantik İlişkilerde Öz Yeterlik Toplam & $.559^{* *}$ & $.555^{* *}$ & 1 \\
\hline
\end{tabular}

${ }^{*} \mathrm{p}<.05,{ }^{* *} \mathrm{p}<.01$

Tablo 4'te görüldüğü gibi, üniversite öğrencilerinin İlişki Sürdürme Stratejileri Ölçeği toplam puanı ile Romantik İlişkilerde Doyum Ölçeği toplam puanı $(\mathrm{r}=.701, \mathrm{p}<.01)$ arasında pozitif yönde yüksek düzeyde; Romantik İlişkilerde Öz Yeterlik Ölçeği toplam puanı $(r=.559, p<.01)$ arasında pozitif yönde orta düzeyde anlamlı ilişki bulunmaktadır. 
İlişki sürdürme stratejileri ile anlamlı düzeyde ilişkileri bulunan romantik ilişki doyumu ve romantik ilişkilerde öz yeterlik toplam ölçek puanlarının, ilişki sürdürme stratejilerinin anlamlı birer yordayıcıları olup olmadıklarını değerlendirmek amacıyla aşamalı regresyon analizi yapılmıştır. Analiz sonuçları Tablo 5'te ve Tablo 6'da sunulmuştur.

Tablo 5. Romantik İlişki Doyumu ve Romantik İlişkilerde Öz Yeterliğin, İlişki Sürdürme Stratejilerini Yordamasına İlişkin Aşamalı Regresyon Analizi Sonuçları

\begin{tabular}{ccccc}
\hline Model & $\mathbf{R}$ & $\mathbf{R}^{2}$ & Düzeltilmiş R & Yordama Hatası \\
& & & & \\
\hline 1 & .701 & .491 & .490 & 15.22 \\
2 & .730 & .533 & .530 & 14.60 \\
\hline
\end{tabular}

Tablo 6. Değişkenlerin B, Beta Korelasyon Katsayıları ve Anlamlılık Düzeyleri

\begin{tabular}{|c|c|c|c|c|c|c|c|c|}
\hline Model & Yordayıcılar & B & $\begin{array}{l}\text { Std. } \\
\text { Hata }\end{array}$ & $\beta$ & $\mathbf{t}$ & $p$ & Tolerance & VIF \\
\hline \multirow[t]{2}{*}{1} & Sabit & 56.096 & 5.395 & & 10.397 & .000 & & \\
\hline & $\begin{array}{l}\text { Romantik İlişki } \\
\text { Doyumu }\end{array}$ & 1.829 & .093 & .701 & 19.743 & .000 & 1.000 & 1.000 \\
\hline \multirow[t]{3}{*}{2} & Sabit & 47.380 & 5.376 & & 8.813 & .000 & & \\
\hline & $\begin{array}{l}\text { Romantik İlişki } \\
\text { Doyumu }\end{array}$ & 1.473 & .107 & .565 & 13.794 & .000 & .692 & 1.445 \\
\hline & $\begin{array}{c}\text { Romantik } \\
\text { İlişkilerde Öz } \\
\text { Yeterlik }\end{array}$ & .367 & .061 & .245 & 5.997 & .000 & .692 & 1.445 \\
\hline
\end{tabular}

Üniversite öğrencilerinin ilişki sürdürme stratejileri düzeylerini yordamak için uygulanan aşamalı çoklu regresyon analizi, iki modelde gerçekleştirilmiştir (Bkz. Tablo 5 ve Tablo 6). Aşamalı regresyon analizinin ilk modelinde üniversite öğrencilerinin ilişki sürdürme stratejileri puanları ile en güçlü korelasyon değerine sahip değişken olarak "romantik ilişki doyumu" değişkeni analize girilmiş, toplam varyansın \%49.1'ini açıklamıştır. İlişki sürdürme stratejileri ile romantik ilişki doyumu puanları arasındaki ikili korelasyon pozitif yönde ve anlamlıdır ( $\left.\mathrm{R}=.701, \mathrm{R}^{2}=.491, \mathrm{p}<.05\right)$. Bu bulgu, romantik ilişki doyumu düzeyi arttıkça ilişki sürdürme stratejileri düzeyinin de arttığını göstermektedir. Ayrıca, regresyon modellerinin tolerans ve varyans şişkinlik faktörü (VIF) değerleri kontrol edildiğinde, çoklu bağlantı probleminin olmadığı söylenebilmektedir.

İkinci regresyon modelinde; romantik ilişki doyumu değişkeninden sonra "romantik ilişkilerde öz yeterlik" değişkeni modele eklenmiş ve bu değişkenin modele eklenmesi ile ilişki sürdürme stratejileri puanında açılanan varyans \%49.1'den \%53.3'e çıkmıştır ( $R=.730$, $\left.\mathrm{R}^{2}=.533\right)$. Diğer bir ifade ile romantik ilişkilerde öz yeterlik değişkeninin açıklanan varyansa \%4.2'lik bir katkısı görülmektedir. Romantik ilişkilerde öz yeterlik değişkenine ait Beta değerinin pozitif olması, romantik ilişki doyumu ve romantik ilişkilerde öz yeterlik ile ilişki sürdürme stratejileri arasındaki ilişkinin pozitif yönde olduğunu, romantik ilişkilerde öz yeterlik düzeyi arttıkça ilişki sürdürme stratejileri düzeyinin de arttığını göstermektedir. Romantik ilişki doyumu ve romantik ilişkilerde öz yeterlik değişkenleri, üniversite 
öğrencilerinin ilişki sürdürme stratejileri puanlarındaki toplam varyansın \%53.3'ünü açıklamaktadır.

\section{İLIŞKİ SÜRDÜRME STRATEJILERI $=47.380$ + 1.473*ROMANTIK İLİŞKİ DOYUMU + .367*ROMANTIK İLİŞKILERDE ÖZ YETERLIKK}

Regresyon denklemi değerlendirildiğinde; romantik ilişkilerde öz yeterlik değişkeni sabit tutulduğunda, romantik ilişki doyumu değişkeni şöyle yorumlanabilmektedir: Romantik ilişki doyum puanlarındaki 1 birimlik artış ilişki sürdürme stratejileri puanlarında 1.473 puanlık bir artışa yol açmaktadır. Romantik ilişki doyumu değişkeni sabit tutulduğunda, romantik ilişkilerde öz yeterlik değişkeni şu şekilde yorumlanabilmektedir: Romantik ilişkilerde öz yeterlik puanlarındaki 1 birimlik artış ilişki sürdürme stratejileri puanlarında ortalama .367 puanlık bir artışa yol açmaktadır. Bulgular; romantik ilişki doyumu ve romantik ilişkilerde öz yeterlik değişkenlerinin, üniversite öğrencilerinin ilişki sürdürme stratejilerinin anlamlı yordayıcıları olduklarını göstermektedir.

\section{TARTIŞMA, SONUÇ ve ÖNERILER}

$\mathrm{Bu}$ çalışmada, üniversite öğrencilerinin romantik ilişki doyumu ve romantik ilişkilerde öz yeterlik düzeylerinin, ilişkileri sürdürme stratejileri üzerindeki yordayıcı rolü incelenmiştir. Araştırma bulguları incelendiğinde, ilişki sürdürme stratejileri ile romantik ilişkilerde doyum ve romantik ilişkilerde öz yeterlik toplam ölçek puanları arasında istatistiksel açıdan anlamlı ilişkiler olduğu tespit edilmiştir. Araştırma bulgularında, üniversite öğrencilerinin ilişki sürdürme stratejileri puanlarının yordanmasına ilişkin aşamalı regresyon analizinin iki aşamada tamamlandığı gözlemlenmektedir. Romantik ilişki doyumu ve romantik ilişkilerde öz yeterlik değişkenlerinin, ilişki sürdürme stratejilerinin anlamlı yordayıcıları olduğu ve bu değişkenlerin üniversite öğrencilerinin ilişki sürdürme stratejileri puanlarına yönelik toplam varyansın \%53.3'ünü açıkladığı tespit edilmiştir. Romantik ilişki doyumu değişkeninin, üniversite öğrencilerinin ilişki sürdürme stratejileri puanlarındaki varyansın \%49.1'ini açıkladığı, romantik ilişkilerde öz yeterlik değişkeninin toplam varyansa getirdiği katkının ise $\% 4.2$ olduğu belirlenmiştir.

Myers, Sweeney ve Witmer (2000), sağlıklı yakın ilişkilerin bazı temel özelliklere sahip olması gerektiğini ifade etmişlerdir. Bu özellikler; (a) güven hissedebilme, romantik ilişki kurabilme (b) sevme-sevilme hissedebilme (c) saygı duyabilme, sevgiyi ifade edebilme, sürdürebilme (d) devamlı, sabit bir yakın ilişkinin varlığını hissedebilme (e) destek alabilme, sağlayabilme (f) haz alınan bir cinsel yaşam, yakınlık ve tensel temasa yönelik ihtiyacı giderebilmedir (Myers ve diğerleri, 2000). Bu özellikleri içeren yakın ilişkiler, sağlıklı bir ilişki olarak nitelendirilebilir. Partnerlerin yakınlık, ait olma, sevgi, cinsellik gibi birtakım önemli ihtiyaçlarının romantik ilişki içerisinde karşılanma düzeyi, ilişki doyumunun sağlanmasında ve artırılmasında oldukça önemli bir etkendir. Bu ihtiyaçların karşılanmaması ya da karşılanma düzeyinin düşük olması durumunda bireyler, ilişkilerine yönelik olumsuz algılara sahip olmakta ve ilişkilerini sürdürüp sürdürmemeye yönelik bazı değerlendirmelerde bulunmaktadır. Yapılan bu değerlendirmeler, ilişki doyumunun belirleyicisidir.

Araştırmada, üniversite öğrencilerinin ilişki sürdürme stratejilerini yordayan en güçlü değişkenin, romantik ilişki doyumu değişkeni olduğu görülmüştür. Çemberci'ye (2019) göre romantik ilişki doyumu, romantik ilişki içerisindeki bireylerin birbirlerine duyduğu sevgi, 
olumlu/olumsuz yaşantıların paylaşılma seviyesi ve ihtiyaçların karşılanma derecesiyle artış gösteren psikolojik bir doyumdur. Partnerlerin romantik ilişkilerini algilama biçimleri ve romantik ilişkilerine yönelik yaptıkları değerlendirmeler onların duygularını, davranışlarını ve motivasyonlarını etkilemektedir (Fincham, 2003). Romantik ilişkide bireyin partneri tarafından olumlu/olumsuz tüm yönleri ile koşulsuz kabulü ilişki doyumunu olumlu yönde etkilerken; reddedilme, eleştirilme ve yargılanma yaşantıları ise ilişki doyumunu olumsuz yönde etkiler. Feeney (2002), romantik partnerlerin olumlu ya da olumsuz davranışlarının ilişki doyumunu etkilediğini ifade etmektedir. Pozitif davranışları koşulsuz kabul, onaylanma ve desteklenme yaşantıları oluştururken; negatif davranışları eleştirme, suçlama, yargılama ve baskı yaşantıları oluşturur. İlişkilerinde doyum hissedemeyen bireylerin, partnerlerine karşı şikâyetçi bir tavır, eleştiri, etkileşimsizlik ve düşmanca bir tavır gibi işlevsel olmayan davranışları daha çok sergileme eğiliminde oldukları gözlemlenmektedir (Fincham ve Beach, 2006).Amato, Booth, Johnson ve Rogers (2007) romantik ilişkilerinde doyumu hisseden partnerlerin, ilişkilerinde olumlu etkileşimler deneyimlediklerini ve daha uzun süreli ilişkiler kurduklarını ifade etmektedir. Bununla birlikte, romantik ilişkilerinde doyumu hisseden partnerlerin, olumsuz duygulanımlara erken müdahalede bulundukları ve onarıcı davranışlar sergiledikleri belirtilir (Fincham ve Beach, 2006). Romantik ilişki doyumu ile ilişki sürdürme stratejileri arasında pozitif yönde anlamlı düzeyde ilişki olduğu saptanmıştır. İlgili alan yazın incelendiğinde; ilişki sürdürme stratejilerinin, romantik ilişki doyumu ile arasındaki ilişkiyi ele alan sınırlı çalışmaya ulaşılmaktadır. Stafford ve Canary (2006) tarafından gerçekleştirilen çalışmada, ilişki doyumunun; pozitiflik, açıklık, güvence, ağ ve görevlerin kullanımı ile ilişkili olduğu tespit edilmiştir. Weigel ve Ballard-Reisch (2008) ise ilişki doyumunun; bireyin hem kendisinin hem de romantik partnerinin, ilişki sürdürme stratejilerini kullanmasıla ilişkili olduğunu saptamıştır. Benzer şekilde, Ogolsky ve Bowers (2013) tarafından, ilişkileri sürdürme ve ilişki doyumunun incelendiği çalışmalara yönelik bir meta-analiz çalışması gerçekleştirilmiştir. Çalışma sonucunda; ilişki sürdürme stratejileri ile ilişki doyumu arasında pozitif yönde anlamlı düzeyde ilişki olduğu saptanmıştır. Belus ve diğerleri (2019) ise gerçekleştirdikleri çalışmada, ilişki doyumunun, ilişki sürdürme davranışları ile bireysel refah arasındaki ilişkiye aracılık ettiğini tespit etmişlerdir. Çelik (2018) gerçekleştirdiği tez çalışmasında, araştırmacılar tarafından geliştirilen yatırım modelini temel alan ilişki sürdürme becerileri psiko-eğitim programının, ilişki istikrarına etkisini incelemiştir. Araştırmanın çalışma grubunu, romantik ilişkisi bulunan 18 'i deney ve 18 'i ise kontrol grubu olmak üzere toplam 36 üniversite öğrencisi oluşturmuştur. Araştırma sonuçlarına göre, ilişki sürdürme becerileri psiko-eğitim programının, ilişki doyumunu, ilişki istikrarını ve ilişkiye yapılan yatırım düzeyini artırdığı tespit edilmiştir. Eren (2019) ise gerçekleştirdiği tez çalışmasında, çevrim içi ilişkiler ile yüz yüze başlayan ilişkileri ilişkisel değişkenler (bağlılık, ilişki doyumu, romantik inançlar, ilişki sürdürme) bağlamında karşılaştırmıştır. Araştırmanın çalışma grubunu, romantik ilişkisi yüz yüze başlayan 276 birey, çevrim içi başlayan 270 birey olmak üzere toplam 546 birey oluşturmuştur. Araştırma sonuçlarına göre, romantik inançların gruplar arası farklılaştığı; ilişki doyumu, ilişki sürdürme davranışları ve bağlılık değişkenlerinin gruplar arası farklılaşmadığı gözlemlenmiştir. Ayrıca, ilişki sürdürme davranışlarının bağlılık, ilişki doyumu ve romantik inançlar ile arasındaki ilişkide aracı rolü üstlendiği tespit edilmiştir. Ruffieux, Nussbeck ve Bodenmann (2014) gerçekleştirdikleri 10 yıllık boylamsal çalışmada, iletişim, stres, iyi oluş ile başa çıkma becerilerinin uzun vadeli ilişki doyumu ve ilişki istikrarı 
üzerindeki etkisini incelemiştir. Araştırmanın çalışma grubunu, 103 çift oluşturmuştur. Araştırma sonuçlarına göre, erkekler ve kadınlar için ilişki doyumunun önemli yordayıcısının ilişki başlangıcındaki ilişki doyumu olduğu; bununla birlikte erkekler için ek olarak ikili başa çıkma becerileri olduğu belirlenmiştir. Ayrıca ilişki doyumunun, ilişki istikrarının önemli yordayıcıları arasında yer aldığı tespit edilmiştir.

İlişki sürdürme stratejilerinin yordanmasına daha düşük düzeyde katkı sağlayan değişkenin, romantik ilişkilerde öz yeterlik değişkeni olduğu belirlenmiştir. Öz yeterlik, bireylerin istenilen sonuçlara ulaşmak için kendi yeteneklerine inanmalarını, süreç boyunca herhangi bir engelle karşılaştıklarında güdülenmelerini ve sabır duygusunun geliştirilmesini sağlamaktadır. Bireylerin sahip oldukları yetenekleri dışında, başarı için gerekli olan davranışlarısergileyebileceklerine yönelik tutarlı bir inanca sahip olmaları gerekmektedir. Tutarlı bir inanca sahip olmayan bireyler, olumsuz geri bildirimlerden, zorluklardan, engellerden ve sınırlamalardan kolayca etkilenmekte, olumsuz bir inanç geliştirmektedirler. Romantik ilişki bağlamında ise, iletişime açı olmak, ilişkiyi beslemek, destekleyici bir rol üstlenmek, öfke, kaygı gibi duyguları kontrol altında tutabilmek şeklindeki davranışlarıyla ilgili bireyin kendine olan güveni, romantik ilişkilerde öz yeterlik olarak ifade edilir (Lopez ve diğerleri, 2007). Araştırma sonucunda, romantik ilişkilerde öz yeterlik ile ilişki sürdürme stratejileri arasında pozitif yönde anlamlı düzeyde ilişki olduğu saptanmıştır. İlgili alan yazın incelendiğinde; ilişki sürdürme stratejilerinin, romantik ilişkilerde öz yeterlik ile arasındaki ilişkiyi ele alan çalışmanın, Weiser ve Weigel (2016) tarafından yürütüldüğü gözlemlenmektedir. Weiser ve Weigel (2016) gerçekleştirdikleri çalışmada, ilişki sürdürme stratejilerinin, romantik ilişkilerde öz-yeterlik ve romantik ilişki doyumu arasındaki ilişkiye aracılık ettiğini tespit etmişlerdir. Diğer bir ifadeyle, daha yetkin bir romantik partner olduklarına inanan bireylerin, ilişki sürdürme stratejilerinin tümünde daha yüksek düzeyde yer aldıkları; ilişki sürdürme stratejilerinin ise, daha yüksek düzeyde romantik ilişki doyumu ile ilişkilendirildiği belirlenmiştir.

Romantik ilişkilerinde daha yüksek düzeyde doyum hisseden ve daha yüksek düzeyde romantik ilişkilerde öz yeterlik algısına sahip bireylerin, romantik ilişkilerini sürdürme eğilimi daha yüksek olmaktadır. Bu bağlamda, üniversite öğrencilerinin romantik ilişki doyumu ve romantik ilişkilerde öz yeterlik düzeylerinin artırılmasına yönelik programların geliştirilmesi ve uygulanması oldukça önem kazanmaktadır. Üniversitelerin psikolojik danışma merkezlerinde (birimlerinde), aile danışmanlığı merkezlerinde, çiftlerle ve ilişki sorunları ile çalışan uygulamacılara, bireylerin ilişki sürdürme stratejileri, romantik ilişki doyumu ve romantik ilişkilerde öz yeterlik düzeylerini artırmaya yönelik, bireyle ve grupla psikolojik danışma, seminer ve psiko-eğitim çalışmaları gerçekleştirmeleri önerilir. Partnerlerin, romantik ilişkilerindeki problem alanlarının belirlenmesi sağlanarak; problemlerin çözülmesi, doyum verici ilişkilerin deneyimlenmesi ve partnerlere ilişkileri sürdürme becerilerinin kazandırılması sağlanabilir. Romantik partnerlerin, sağlıklı bağlanımlarının desteklenmesini sağlayan ilişki dinamiklerinin belirlenmesini hedefleyen ilişki sürdürmeye/ilişki geliştirmeye yönelik programların geliştirilmesi ve uygulanması önerilir.

İlgili alan yazında, yurt içinde, mevcut çalışmadaki değişkenlerin birlikte ele alındı̆̆ı herhangi bir çalışmaya ulaşılamamıştır. Yurt dışında ise mevcut çalışmaların oldukça sınırlılık gösterdiği; yer alan çalışmaların ise daha çok ilişki sürdürme stratejileri ile ilişki doyumu 
değişkenlerine yönelik gerçekleştirildiği gözlemlenmektedir. Ayrıca, konuyla ilgili yürütülen araştırmalarda, çalışma grubunun daha çok çiftlerden ve yetişkinlerden oluştuğu görülmektedir. Dolayısıyla, konuyla ilgili yürütülecek çalışmaların, romantik ilişki inançları, romantik ilişki kalitesi, romantik ilişki durumu gibi farklı değişkenlerle ele alınması ve ergenler, beliren yetişkinler gibi farklı çalışma gruplarıyla yürütülmesi önerilmektedir.

Romantik ilişki doyumunun ve romantik ilişkilerde öz yeterliğin, üniversite öğrencilerinin ilişki sürdürme stratejileri düzeyleri üzerindeki etkisinin belirlendiği bu çalışmada, üniversite öğrencilerinin ilişki sürdürme stratejileri düzeyleri sınırlı sayıda değişkenle ele alınmıştır. Mevcut araştırma bulguları, romantik ilişki doyumunun ve romantik ilişkilerde öz yeterliğin ilişki sürdürme stratejilerine yönelik varyansın \%53.3'ünü açıladığını ortaya koymaktadır. Açıklanamayan varyans ise, ilişki sürdürme stratejilerinin farklı yordayıcılarının olduğuna dikkatleri çekmektedir. Bu bağlamda ilişki sürdürme stratejilerinin romantik ilişki istikrarı, romantik ilişki biçemleri gibi farklı değişkenlerle ele alınmasının ilgili alan yazına katkı sağlayacağı düşünülmektedir.

İlişki sürdürme stratejileri, romantik ilişki doyumunun ve romantik ilişkilerde öz yeterliğin geliştirilmesine yönelik deneysel çalışmaların yapılması önerilmektedir. Böylelikle, yürütülecek deneysel programların, bu değişkenler üzerinde etkililikleri ele alınabilir. Mevcut çalışmanın nicel bir çalışma niteliği taşıması göz önünde bulundurularak, yürütülecek yeni çalışmalarda, nitel ve karma araştırma yöntemlerinin kullanılmasıyla, çalışmanın farklı bakış açıları ile değerlendirilmesi sağlanabilir.

Araştırmanın bulgularının değerlendirilmesinde, araştırma sınırlılıklarının da göz önünde bulundurulması gerekmektedir. Araştırmadan elde edilen bulgular, Ege Bölgesi'nde yer alan bir devlet üniversitesinin Eğitim Fakültesi, Hukuk Fakültesi, Fen ve Edebiyat Fakültesi, İktisadi ve İdari Bilimler Fakültesi, Mühendislik Fakültesi, Mimarlık Fakültesi, Tıp Fakültesi, Hemşirelik Fakültesi, Diş Hekimliği Fakültesi ve Sağlık Bilimleri Fakültesi'nde öğrenim gören öğrencilerden elde edilen verilerle sınırlıdır. Araştırmada belirli bir örneklem grubu ile çalışılması, araştırma bulgularının genellenmesine olanak tanıamamaktadır. Dolayısıyla, farklı gelişimsel dönemde yer alan, farklı sosyo-ekonomik kültürel düzeylere sahip bireylerle, farklı yakın ilişkiler bağlamında (arkadaş, kardeş ilişkileri gibi) ilişki sürdürme stratejilerine yönelik çalışmaların yürütülmesi, konuyla ilgili daha fazla bilgi edinilmesini sağlayacaktır. Bunlara ek olarak, ilişkileri sürdürme stratejilerinin, toplumsal cinsiyet rollerine göre farklılaşıp farklılaşmadığının da incelenmesi önerilmektedir. 


\section{KAYNAKÇA}

Bandura, A. (1994). Self-efficacy, In V. S. Ramachaudran (Ed.). Encyclopedia of Human Behavior, 4, 71-81, Academic Press.

Belus, J. M., Pentel, K. Z., Cohen, M. J., Fischer, M. S. \& Baucom, D. H. (2019). Staying connected: An examination of relationship maintenance behaviors in long-distance relationships. Marriage and Family Review, 55(1), 78-98. https://doi.org/10.1080/01494929.2018.1458004

Brewer, G. \& Abell, L. (2017). Machiavellianism, relationship satisfaction, and romantic relationship quality. Europe's Journal of Psychology, 13(3), 491-502. https://dx.doi.org/10.5964\%2Fejop.v13i3.1217

Büyüköztürk, Ş., Kılıç Çakmak, E., Akgün, Ö.E., Karadeniz, Ş. \& Demirel, F. (2018). Bilimsel araştırma yöntemleri. (24. Bask1). Pegem Akademi Yayıncılık.

Canary, D. J. \& Dainton, M. A. (2006). Maintaining relationships. In A. L. Vangelisti ve D. Perlman (Ed.). The Cambridge handbook of personal relationships. (pp. 727-745). Cambridge University Press.

Canary, D. J. \& Stafford, L. (1992). Relational maintenance strategies and equity in marriage. Communication Monographs, 59(3), 243-267. https://doi.org/10.1080/03637759209376268

Canary, D. J., Stafford, L. \& Semic, B. A. (2002). A panel study of the associations between maintenance strategies and relational characteristics. Journal of Marriage and the Family, 64(2), 395-406. https://doi.org/10.1111/j.1741-3737.2002.00395.x

Collins, W. A. (2003). More and myth: the developmental significance of romantic relationships during adolescence. Journal of Research on Adolescence, 13(1), 1-24. https://doi.org/10.1111/1532-7795.1301001

Cramer, D. (2002). Linking conflict management behaviours and relational satisfaction: The intervening role of conflict outcome satisfaction. Journal of Social and Personal Relationships, 19(3), 425-432. https://doi.org/10.1177\%2F0265407502193007

Cramer, D. (2004). Satisfaction with a romantic relationship, depression, support and conflict. Psychology and Psychotherapy, 77(4), 449-461. https://doi.org/10.1348/1476083042555389

Cui, M., Fincham, F. D. \& Pasley, B. K. (2008). Young adult romantic relationships: The role of parents' marital problems and relationship efficacy. Personality and Social Psychology Bulletin, 34(9), 1226-1235. https://doi.org/10.1177\%2F0146167208319693

Çelik, D. B. (2018). Yatırım modeline dayalı evlilik öncesi ilişki sürdürme becerileri psiko-eğitim grubunun ilişki istikrarına etkisinin incelenmesi. Doktora tezi, Çukurova Üniversitesi, Adana.

Dindia, K. (2000). Sex differences in self-disclosure, reciprocity of self-disclosure, and selfdisclosure and liking: Three meta-analyses reviewed. In S. Petronio (Ed.), Balancing the secrets of private disclosures (pp. 21-36). Erlbaum.

Duck, S. (1988). Relating to others. Dorsey. 
Eren, D. E. (2019). Comparison of online vs. offline dating in terms of romantic beliefs, commitment, relationship maintenance and relationship satisfaction. Yüksek lisans tezi, Özyeğin Üniversitesi, İstanbul.

Feeney, J. A. (2002). Attachment, marital interaction, and relationship satisfaction: A diary study. Personal Relationships, 9(1), 39-55. https://doi.org/10.1111/1475-6811.00003

Fincham, F. D. (2003). Marital conflict: Correlates, structure, and context. American Psychological Society, 12(1), 23-27. https://doi.org/10.1111\%2F1467-8721.01215

Fincham, F. D., Harold, G. T. \& Gano-Phillips, S. (2000). The longitudinal association between attributions and marital satisfaction: Direction of effects and role of efficacy expectations. Journal of Family Psychology, 14(2), 267-285. https://psycnet.apa.org/doi/10.1037/0893-3200.14.2.267

Gleeson, G. \& Fitzgerald, A. (2014). Exploring the association between adult attachment styles in romantic relationships, perceptions of parents from childhood and relationship satisfaction. Health, 6(13), 1643-1661. http://www.scirp.org/journal/PaperInformation.aspx?PaperID=47883

Gündüz, B. \& Karataş, A. (2020, Eylül). İlişki doyumunun yordayıcıları: İlişkisel benlik değişimi ve romantik ilişkilerde öz yeterlik. Eğitim Araştırmaları Kongresi, Mustafa Kemal Üniversitesi, Hatay.

Hendrick, S. S. \& Hendrick, C. (2006). Measuring respect in close relationships. Journal of $\begin{array}{lll}\text { Social and Personal 23(6), 881-899. } & \text { Relationships, }\end{array}$ https://doi.org/10.1177\%2F0265407506070471

Kuttler, A. F. \& Greca, A. M. L. (2004). Linkages among adolescent girls'romantic relationships, best friendships and peer networks. Journal of Adolescence, 27, 395- 414. https://doi.org/10.1016/j.adolescence.2004.05.002

Lopez, F.G., Morúa, W. \& Rice, K.G. (2007). Factor structure, stability, and predictive validity of college students' relationship self-efficacy beliefs. Measurement and Evaluation in Counseling and Development, 40, 80-96. https://doi.org/10.1080/07481756.2007.11909807

Myers, J. E., Sweeney, T. J. \& Witmer, J. M. (2000). The wheel of wellness counseling for weinness: a holistic model for treatmentplanning. Journal of Counseling and Development, 78(3), 251-266. https://doi.org/10.1002/j.1556-6676.2000.tb01906.x

Ogolsky, B. G. \& Bowers, J. R. (2013). A meta-analytic review of relationship maintenance and its correlates. Journal of Social and Personal Relationships, 30(3), 343-367. https://doi.org/10.1177\%2F0265407512463338

Öz Soysal, F. S., Uz Baş, A. \& Aysan, F. (2019a). İlişkileri sürdürme stratejileri ölçeği geçerlik ve güvenirlik çalışması. Elektronik Sosyal Bilimler Dergisi, 18(70), 710-719. https://doi.org/10.17755/esosder.446014

Öz Soysal, F. S., Uz Baş, A. \& Aysan, F. (2019b). Romantik ilişkilerde öz yeterlik ölçeği geçerlik ve güvenirlik çalışması. Insan ve Toplum Bilimleri Araştırmaları Dergisi, 8(2), 1100-1110. https://doi.org/10.15869/itobiad.544395 
Riggio, H. R., Weiser, D. A., Valenzuela, A. M., Lui, P. P, Montes, R. \& Heuer, J. (2011). Initial validation of a measure of self efficacy in romantic relationships. Personality and Individual Differences, 51, 601-606. https://doi.org/10.1016/j.paid.2011.05.026

Roberts, A. \& Pistole, M. C. (2009). Long distance and proximal romantic relationship satisfaction: Attachment and closeness predictors. Journal of College Counseling, 12(1), 5-17. https://doi.org/10.1002/j.2161-1882.2009.tb00036.x

Ruffieux, M., Nussbeck, F. W. \& Bodenmann, G. (2014). Long-term prediction of relationship satisfaction and stability by stress, coping, communication, and wellbeing. Journal of Divorce and Remarriage, 55(6), 485-501. https://doi.org/10.1080/10502556.2014.931767

Rusbult, C. E. \& Buunk, B. P. (1993). Commitment processes in close relationships: An interdependence analysis. Journal of Social and Personal Relationships, 10, 175-204. https://doi.org/10.1177\%2F026540759301000202

Rusbult, C. E., Olsen, N., Davis, J. L. \& Hannon, P. A. (2001). Commitment and relationship maintenance mechanisms. In Close romantic relationships: Maintenance and enhancement. (pp. 87 113). Erlbaum.

Sakallı-Uğurlu, N. (2003). How do romantic relationship satisfaction, gender stereotypes, and gender relate to future time orientation in romantic relationships?. The Journal of Psychology: Interdisciplinary and Applied, 137(3), 294-303. https://doi.org/10.1080/00223980309600615

Saraç, A., Hamamcl, Z. \& Güçray, S. (2015). Üniversite öğrencilerinin romantik ilişki doyumunu yordaması. Türk Psikolojik Danışma ve Rehberlik Dergisi, 5(43), 69-81.

Sarı, T. (2008). Üniversite öğrencilerinin romantik ilişkilerle ilgili akılcı olmayan inançlar, bağlanma boyutları ve ilişki doyumu arasındaki ilişkiler. Doktora tezi, Hacettepe Üniversitesi, Ankara.

Stackert, R. A. \& Bursik, K. (2003). Why i unsatisfied? Adult attachment style, gendered irrational relationship beliefs, and young adult romantic relationship satisfaction. Personality and Individual Differences,34(8), 1419- 1429. https://doi.org/10.1016/S0191$\underline{8869(02) 00124-1}$

Stafford L. \& Canary, D. J. (1991). Maintenance strategies and romantic relationship type, gender, and relational characteristics. Journal of Social and Personal Relationships, 8(2), 217-242. https://doi.org/10.1177\%2F0265407591082004

Stafford, L. \& Canary, D. J. (2006). Equity and interdependence as predictors of relational maintenance strategies. Journal of Family Communication, 6(4), 227-254. https://doi.org/10.1207/s15327698jffc0604_1

Tabachnick, B. G. \& Fidell, L. S. (2015). Çok değişkenli istatistiklerin kullanımı. (M. Baloğlu, Çev.). Nobel Yayın Dağıtım.

Weigel, D. J. \& Ballard-Reisch, D. S. (2008). Relational maintenance, satisfaction, and commitment in marriages: An actor-partner analysis. Journal of Family Communication, 8, 212-229. https://doi.org/10.1080/15267430802182522 
Weiser, D. A. \& Weigel, D. J. (2016). Self-efficacy in romantic relationships: Direct and indirect effects on relationship maintenance and satisfaction. Personality and Individual Differences, 89, 152- 156. https://doi.org/10.1016/j.paid.2015.10.013

Wenzel, A. \& Harvey, J. (2001). Introduction: The movement toward studying the maintenance and enhancement of close romantic relationships. In J. Harvey ve A. Wenzel (Ed.). Close romantic relationships: Maintenance and enhancement (pp. 1-10). Lawrence Erlbaum Associates. 